\title{
Signet Ring Melanoma
}

National Cancer Institute

\section{Source}

National Cancer Institute. Signet Ring Melanoma. NCI Thesaurus. Code C54663.

A rare variant of cutaneous melanoma, characterized by the presence of malignant cells with signet-ring morphology. 